\title{
ESG-persistence in Socially Responsible Mutual Funds
}

\author{
Maximilian Wimmer ${ }^{1}$ \\ ${ }^{1}$ Department of Finance, University or Regensburg, Regensburg, Germany \\ Correspondence: Maximilian Wimmer, Department of Finance, University of Regensburg, 93040 Regensburg, \\ Germany. Tel: 49-941-943-2672. E-mail: maximilian.wimmer@ur.de
}

Received: July 26, 2012 Accepted: August 10, 2012 Online Published: October 9, 2012

doi:10.5539/jms.v3n1p9 URL: http://dx.doi.org/10.5539/jms.v3n1p9

\begin{abstract}
This paper analyzes the persistence of environmental, social, and governance (ESG)-scores in socially responsible (SR) mutual funds. ESG-scores can be used as a measure for the level of social responsibility of an SR mutual fund. It is shown that ESG-scores persist for approximately two years. However, the persistence of the ESG-scores is terminated after approximately three years. This implies that value-driven investors of SR mutual funds who seek high-ESG investments cannot rely upon a long-term continuation of high ESG-scores and thus need to rebalance their portfolio from time to time. The lack of long-term persistence in the ESG-scores is caused by changes in the holdings of the SR mutual funds.
\end{abstract}

Keywords: socially responsible investing, ESG-scores, corporate social responsibility, persistence

\section{Introduction}

Socially responsible investing (SRI), which is sometimes also called ethical investing or sustainable investing, is attracting increasing attention both in practice and in academia (Renneboog, Ter Horst, \& Zhang, 2008a; Capelle-Blancard \& Monjon, 2012). According to the US Social Investment Forum [US SIF] (2010) trend report, a total of $\$ 316.1$ billion was invested in socially responsible (SR) mutual funds in the United States in 2010. On the demand side, Derwall, Koedijk, and Ter Horst (2011) categorize socially responsible investors into two groups: Value-driven investors, who mainly pursue social or sustainable values rather than strictly financial ones, and profit-seeking investors, who consider SRI as a tool to generate superior financial performance.

For profit-seeking investors there is a bulk of academic literature concerning the question on whether SRI can improve financial performance, although the results are not always conclusive. While some contributions (Moskowitz, 1972; Luck \& Pilotte, 1993; Derwall, Guenster, Bauer, \& Koedijk, 2005; Kempf \& Osthoff, 2007; Edmans, 2011) confirm a superior financial performance for certain socially responsible screens, most studies, however, do either find no difference in the performance of SRI and traditional investments (Hamilton, Jo, \& Statman, 1993; Kurtz \& DiBartolomeo, 1996; Guerard, 1997; Bauer, Koedijk, \& Otten, 2005; Schröder, 2007; Statman \& Glushkov, 2008) or even negative performance (Brammer, Brooks, \& Palvin, 2006; Renneboog, Ter Horst, \& Zhang, 2008b; Hong \& Kacperczyk, 2009; Mănescu, 2010). Another branch of literature analyzes the persistence of the financial performance of mutual funds in general (e.g. Hendricks, Patel, \& Zeckhauser, 1993; Carhart, 1997; Bollen, 2005). These studies converge that there is no evidence that fund managers are able to consistently generate financial over-performance for more than one year.

This study, on the other hand, is relevant for value-driven investors of SR mutual funds. For such investors, the financial performance is not the ultimate measure. Instead, these investors seek to integrate corporate social responsibility (CSR) criteria into their investment decision (Bollen, 2007; Derwall et al., 2011). Although it is hard to quantify social responsibility in general, CSR-criteria are usually measured in terms of environmental, social, and governance (ESG) issues (US SIF, 2010) and condensed into a single composite ESG-score for each company (Note 1). Thereby, it is also possible to quantify the ESG-score of an SR mutual fund by considering the ESG-scores of the individual assets in its holdings. While there are a lot of mutual funds available, which are generally classified as being socially responsible, it is also clear that the individual level of social responsibility, i.e., the ESG-scores, varies between the funds. It appears surprising that little attention has been given to the extra-financial performance of SR mutual funds in the literature, as Capelle-Blancard and Monjon (2012) recently pointed out.

This article partly bridges this gap by analyzing the persistence of the ESG-scores of SR mutual funds. I 
demonstrate that funds with a high ESG-score maintain a high score for two years on average, whereas their ESG-score drops considerably afterwards. This finding has profound implications for value-driven investors who seek to invest their wealth in funds with a high ESG-score. While such investors can search for an SR mutual fund with an ESG-score, which is currently high, and eventually invest in it, they cannot rely upon a long-term continuation of the high ESG-scores.

Furthermore, I find that changes in the funds' portfolios mainly account for the change of the funds' ESG-scores. This implies that the lack of long-term persistence in the ESG-scores is not mainly caused by an increase or decrease of CSR on a company-level, but by the lack of appreciation of the SR mutual fund managers.

Although value-driven investors are most certainly also interested in the financial performance of their investments, this study does not cover the financial performance of SRI at all. While a lot of research has been conducted solely on the financial performance of SRI (see the references above), recent papers highlight that value-driven investors face a trade-off between financial return and CSR in their portfolio selection (e.g. Barracchini \& Adessi, 2012; Dorfleitner \& Utz, 2012). Yet, the question of whether a currently high ESG-score of any portfolio continues to persist in the future remains. This is the focus of this paper.

The remainder of this article is organized as follows. In Section 2, I introduce the data and the precise methodology employed in this study. The main results are reported and discussed in Section 3. Finally, Section 4 summarizes and concludes the paper.

\section{Methodology}

\subsection{Data}

The data for this study stems from several sources. I begin with a list of mutual funds that are classified as being socially responsible, which I obtained from the US SIF website (http://ussif.org/resources/mfpc/screening.cfm). This list contains a comprehensive sample of all socially responsible screened mutual funds in the United States. Next, I link the list with the Center for Research in Security Prices (CRSP) Survivor-Bias-Free US Mutual Fund Database, which contains the exact holdings of the funds on different reporting dates (usually either quarterly or yearly) from 2003 through 2009. Finally, I obtain the ESG-scores for the individual securities of the funds' holdings from the ASSET4 database of Thomson Reuters Datastream. The ESG-scores range from zero to one hundred, which I will interpret as percentage values in the following. To be precise, the ESG-score of a firm is calculated as the average of the firm's individual scores on environmental, social, and corporate governance issues (Note 2). To compute the ESG-score of a fund on a particular reporting date, I weight the latest available ESG-scores before the reporting date according to the securities' portions of the fund's holding. Although ESG-scores are available for approximately 1800 different securities, I have to omit certain funds on particular reporting dates due to incomplete data support. In particular, I filter out all fund compositions for which less than 70 percent of the fund's holding is covered by available ESG-scores. In the end, there remain 27 different mutual funds, for which I have a total 276 fund composition with ESG-scores available.

Table 1. Descriptive data statistics ordered by year

\begin{tabular}{|c|c|c|c|c|c|c|c|}
\hline Year & 2003 & 2004 & 2005 & 2006 & 2007 & 2008 & 2009 \\
\hline $\begin{array}{l}\text { No. of fund compositions } \\
\text { (frequency as reported by the funds) }\end{array}$ & 8 & 20 & 32 & 34 & 33 & 51 & 96 \\
\hline $\begin{array}{l}\text { No. of fund compositions } \\
\text { (normalized to yearly frequency) }\end{array}$ & 5 & 8 & 10 & 12 & 12 & 23 & 21 \\
\hline Avg. ESG-score & $61.1 \%$ & $65.3 \%$ & $65.6 \%$ & $66.8 \%$ & $67.6 \%$ & $67.2 \%$ & $67.4 \%$ \\
\hline
\end{tabular}

Description: The table reports the total number of fund compositions, the total number of fund compositions after normalizing to a yearly basis, as well as the average of the funds' ESG-scores grouped by year.

Table 1 reports the distribution of the 274 fund compositions over the years. Especially in the years 2003 and 2004 there are only few fund compositions available, which is due to two reasons. Firstly, some of the SR mutual funds in the US SIF list are fairly young and did not exist prior to these dates. Secondly, the universe of ESG-rated securities was considerably smaller. This yields more excluded fund compositions due to the 70 percent coverage threshold introduced above. Moreover, Table 1 highlights the fact that the average ESG-scores of the funds increased between 2003 and 2006, and seem to have leveled off at about 67 to 68 percent thereafter. 
Since ESG-scores are updated only yearly, it is advisable to also consider the SR mutual funds on a yearly basis. This does not cause a problem for funds that report their holdings only yearly, but since most funds report their holdings quarterly, a degree of adaptation is necessary. In particular, for each fund I take the average of all ESG-scores of the different reporting dates in one year as the fund's overall ESG-score in that particular year. Of course, this yields a decrease of the total sample of available fund compositions. The final distribution of the fund compositions on the normalized yearly timescale is also reported in Table 1. Although the final sample size (91 fund compositions) may appear to be rather small, it is noteworthy that the sample generates clear statistical patterns (seen in Section 3 below), which suggests that increasing the sample size may have only limited incremental value for this study.

\subsection{Ranking}

Following the approach of Hendricks et al. (1993) and Carhart (1997), who analyze the financial persistence of mutual funds, I rank the mutual funds according to their overall ESG-score each year dating from 2003 to 2009. Afterwards, I construct four equally weighted portfolios corresponding to the respective quartiles of the funds. Thereby, for instance, portfolio 1 contains the 25 percent of all funds with the highest ESG-scores in a certain year, whereas portfolio 4 contains the 25 percent of all funds with the lowest ESG-scores in that year. Notice that since the number of fund compositions is not divisible by four in all years, there may be funds that rest exactly on the threshold between two rank portfolios. In such cases, I put the respective fund into both adjacent rank portfolios, each with half-weight (Note 3).

\section{Results and Discussion}

I report the results depending on the time horizon of the investment. In particular, I define a short-term horizon as exactly one year, a mid-term horizon as one to three years, and a long-term horizon as three or more years.

\subsection{Results for Short-term Persistence}

To assess the level of persistence of funds' ESG-scores, I compute the contingency table of the one-year ranking transition. This table shows a fund's probability of falling into each rank portfolio in the subsequent year depending on the fund's current rank portfolio. Figure 1 displays this table, i.e., the bars in the figure display the probabilities $\operatorname{Pr}[\operatorname{rank} i$ in the following year $\mid \operatorname{rank} j$ in the current year].

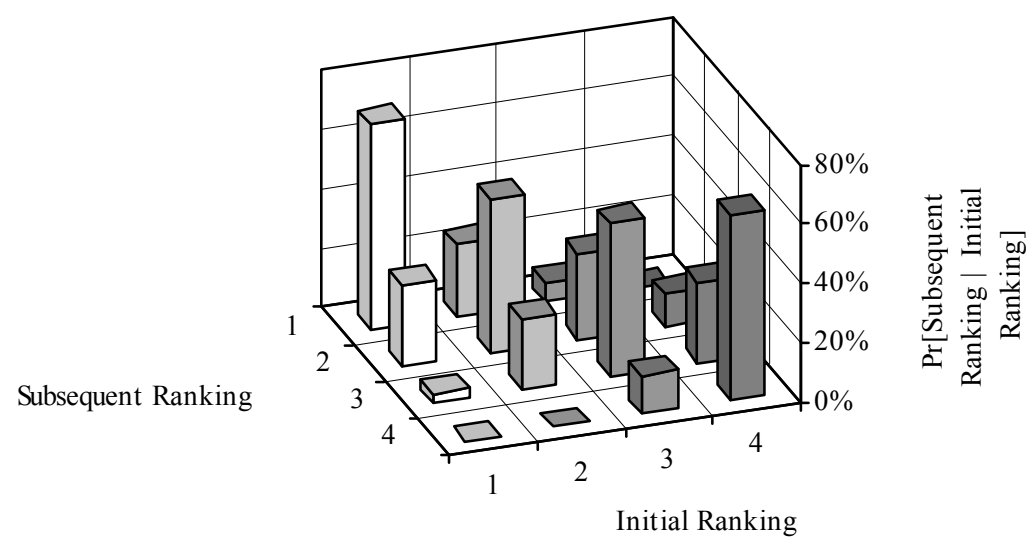

Figure 1. Contingency table of ESG ranking transitions

Description: In each calendar year from 2003 to 2009, funds are ranked in quartile portfolios based on their ESG-scores. These initial rankings are paired with the funds' rankings one year later. Thus, the bar in a cell $(i, j)$ represents the conditional probability of obtaining a subsequent ranking of quartile $i$ given an initial ranking of quartile $j$.

From Figure 1 it becomes apparent that the ESG-scores of SR mutual funds are quite persistent on a one-year horizon. This can also be confirmed by a Spearman correlation test, which yields a significant non-zero correlation on an arbitrary confidence level $\left(p<10^{-12}\right)$ between the initial and the subsequent ranking. In general, for all initial rankings the fund is most likely to remain in its ranking portfolio in the following year. Yet, when detailing the table further, the highest probabilities appear for a fund in the top quartile (initial ranking 1) to 
remain in the top quartile with a probability of 69.0 percent, and for a fund in the bottom quartile to remain in the bottom quartile with a probability of 62.2 percent. These figures highlight a strong "winners stay winners" and "losers stay losers" effect in the ESG-ranking.

\subsection{Results for Longer-term Persistence}

To analyze whether the high ESG-scores tend to be either short-lived or persist over several years, I calculate the average ESG-scores of the four rank portfolios in their formation year, as well as the average ESG-scores of these four portfolios in the subsequent four years. In this calculation, the portfolios are not rebalanced after each year. Figure 2 displays the development of the average ESG-scores of these four portfolios from the formation year for a period of four years. Since the portfolios are constructed in the original formation year by the ranking of the ESG-scores of the respective funds, it is clear that portfolio 1, which contains exactly the funds with the highest ESG-scores in that year, shows the highest ESG-score, portfolio 2 the second highest ESG-score, and so on, in the formation year. The figure also displays that the top portfolio (portfolio 1) remains the portfolio with the highest average ESG-score for the following two years, and the bottom portfolio (portfolio 4) remains the portfolio with the lowest average ESG-score for the next three years. However, the differences in the average ESG-scores become smaller, and may even slightly revert four years after the formation year. In particular, the initial top portfolio shows the lowest average ESG-score four years later.

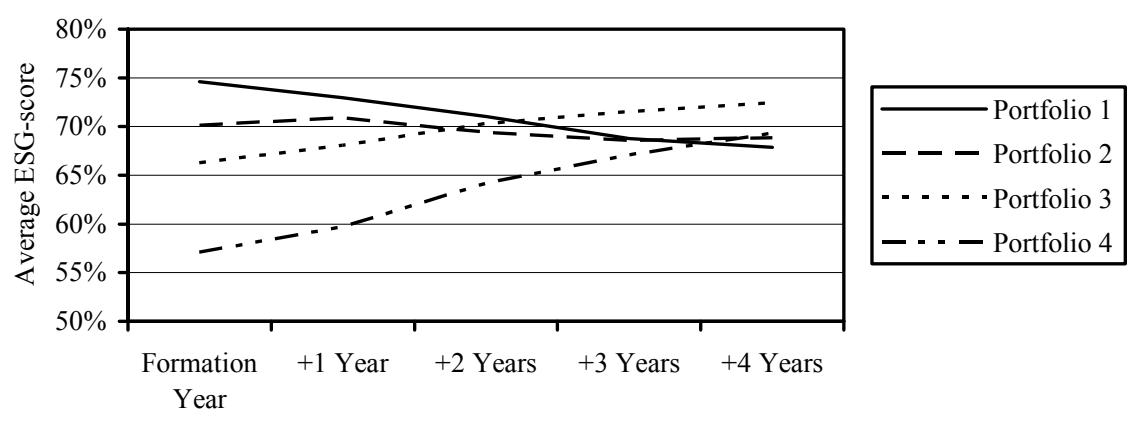

Figure 2. Post-formation ESG-scores of portfolios of socially responsible mutual funds sorted on ESG-scores

Description: In each calendar year from 2003 to 2009, funds are ranked into equal-weight quartile portfolios based on their ESG-scores. The lines in the graph represent the ESG-scores of the four portfolios in the ensuing one to four years subsequent to their formation. Funds that initially have the highest quartile of ESG-score comprise portfolio 1, whereas funds that initially have the lowest quartile of ESG-scores comprise portfolio 4.

Notice, however, that Figure 2 presents only descriptive data. To find statistical evidence, I calculate the Spearman correlation of the rank (in the usual quartiles) of each mutual fund within a year and its rank one to four years later. The results are displayed in Table 2. On the one hand, the numbers show a significant persistence of the ESG-score ranking for the first two years. On the other hand, the negative correlations three and four years after the initial ranking hint that there might even be a reversal of the ESG-score ranking, even though the correlations are not statistically significantly non-zero. In any case, it should be noted that there is no empirical evidence of persisting ESG-scores after three and four years.

Table 2. Significance tests of ESG-score persistence.

\begin{tabular}{lcccc}
\hline Lag & +1 Year & +2 Years & +3 Years & +4 Years \\
\hline$n$ & 63 & 39 & 26 & 16 \\
Spearman-Correlation & 0.77 & 0.33 & -0.09 & -0.32 \\
$p$-value (Significance) & $0.0000^{* * *}$ & $0.0407^{* *}$ & 0.6500 & 0.2251 \\
\hline
\end{tabular}

Description: The table states the correlations of the quartile of each fund's ESG-score in one year and of the quartile of the respective fund's ESG-score in the subsequent one to four years. I report the number of observations $n$, the Spearman correlation coefficient, and the $p$-value according to the Spearman nonparametric test on rank ordering. $* * *, * *$, and $*$ denote non-zero correlations at significance levels of $1 \%, 5 \%$, and $10 \%$, respectively. 


\subsection{Discussion}

In principle, a lack of long-term persistence of the ESG-scores could be attributed to two reasons: Firstly, an SR mutual fund manager can change his or her portfolio, which effects an immediate change of the portfolio-wide ESG-score. If, for instance, a fund's manager decides to abandon an asset with a high ESG-score and replaces it with an asset with a lower ESG-score, the portfolio's ESG-score will decrease. Vice versa, replacing a low-ESG asset with a high-ESG asset pushes the portfolio's ESG-score up. Secondly, a portfolio's ESG-score could also change if there was no trading in the portfolio. ESG-scores are evaluated annually, and each firm-specific ESG-score can increase or decrease depending on the firm's efforts with respect to environmental, social, and governance issues. Since a fund's ESG-score is calculated as the weighted mean of its individual assets' ESG-scores, a change in an individual ESG-score also yields a change in the fund's ESG-score.

To analyze what exactly causes the lack of long-term persistence-portfolio turnover or changes in firms' ESG-scores-I perform a similar analysis to that seen in Figure 2 above. However, this time I do not consider the actual funds' holdings one to four years after the formation of the four rank portfolios, which change due to trading of the funds' managers. Instead, I virtually keep the funds' holdings fixed to their initial holdings. Thereby, a change in the rank portfolios' ESG-scores is solely driven by a change of the firms' ESG-scores. The results of this analysis are displayed in Figure 3. In contrast to the results of Figure 2, the rank portfolios here show a high level of persistence in the average ESG-scores. The ranking of all portfolios remains identical for the analyzed four years. For instance, portfolio 1, which is formed by the quartile containing the funds with the highest ESG-scores in the formation year, remains the top portfolio each of the following four years. Similarly, portfolio 4 remains the bottom portfolio throughout the subsequent four years. When examining Figure 3 further, it seems apparent that the average ESG-scores of all portfolios increase after their formation. This is due to the fact that the ESG-scores have generally increased during the period covered by the data (cf. Table 1).

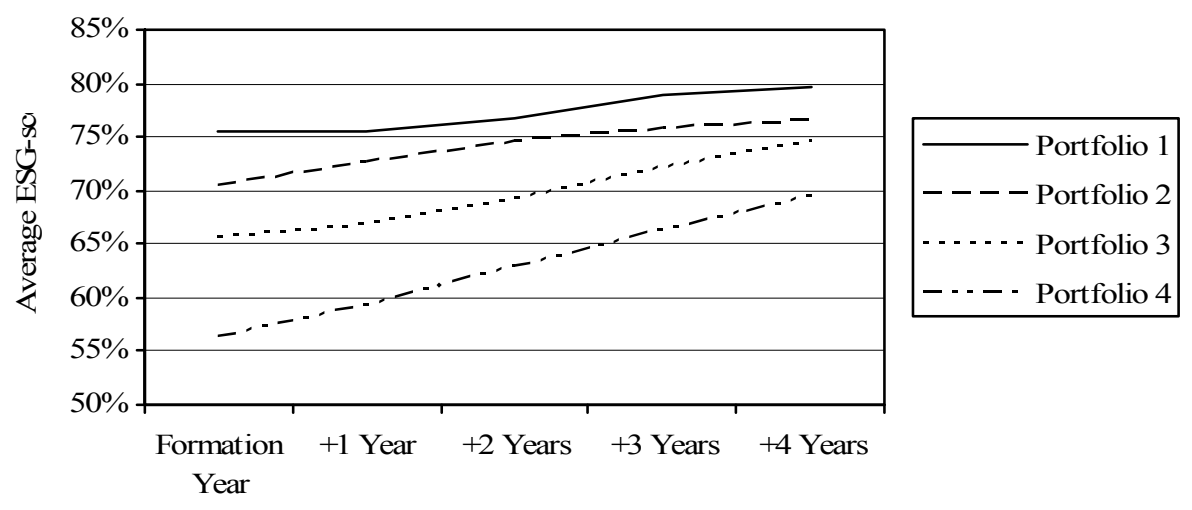

Figure 3. Post-formation ESG-scores of fixed portfolios of socially responsible mutual funds sorted on ESG-scores

Description: In each calendar year from 2003 to 2009, funds are ranked into equal-weight quartile portfolios based on their ESG-scores. The lines in the graph represent the ESG-scores of the four portfolios in the ensuing one to four years subsequent to their formation on the assumption that the funds' holdings remain equal over the four years. Funds that initially have the highest quartile of ESG-score comprise portfolio 1, whereas funds that initially have the lowest quartile of ESG-scores comprise portfolio 4.

Figure 3 provides clear evidence that if fund managers were not to change their portfolio, then the portfolios would exhibit a long-term persistence in the ESG-scores, despite of the yearly re-evaluation of the firms' CSR-efforts. Therefore, I also conclude that the observed convergence of ESG-scores two to three years after the rank portfolio formation in Figure 2 must be attributed to changes in the funds' portfolios. This implies that in particular those managers of SR mutual funds that currently exhibit a high ESG-score appear not to appreciate their ESG-score to a very large degree. Instead, they seem to be willing to accept a lower fund-wide ESG-score when re-allocating their total wealth among different assets.

This result implies that individual investors, who seek to invest in assets with a high ESG-score, cannot simply invest in one or more SR mutual funds with a currently high ESG-score, and to "sit back" for several years leaving their portfolio unchanged in the hope that the high ESG-scores of their selected funds persist. Instead, 
these investors need to carefully evaluate the holdings and ESG-scores of the funds they have invested in at least every two to three years. If a fund's ESG-score has decreased significantly, it would be advisable to become active and replace that fund with a superior one.

\section{Summary and Conclusion}

SR mutual funds are an attractive investment vehicle for value-driven socially responsible investors. While certain SR investors have a relatively specific understanding of what exactly they consider to be 'socially responsible', for instance not investing in tobacco and in the arms industries, many SR investors have only a vague idea and simply aim to invest in firms with a high corporate social responsibility profile (cf. Hill, Ainscough, Shank \& Manullang, 2007). The scores on ESG issues are the industry-standard to evaluate and quantify corporate social responsibility.

While a lot of research has been published on the financial performance of SR mutual funds, this is, to the best of my knowledge, the first article to analyze the persisting performance of SR mutual funds when it comes to the social component. The main finding of this article is that investors can rely upon a persisting high ESG-score for approximately two years subsequent to investing in a high-ESG fund. While this period is relatively long compared to the persistence of financial performances reported in the literature, investors who seek to see their wealth invested in firms with a high CSR profile still need to monitor their investment from time to ensure that their SR mutual fund is still invested in firms with a high level of CSR commitment.

This research also suggests that there is a lack of appreciation of CSR issues among managers of SR mutual funds. This might be due to the fact that most SR mutual funds conduct very specific asset selection policies by filtering out improper assets through a screening process in the first stage and by performing a strictly financial optimization in the second stage. While some research on how SR mutual funds can include ESG-scores in the optimization in the second stage has recently been published (e.g. Barracchini \& Adessi, 2012; Dorfleitner \& Utz, 2012), it still remains to be implemented in practice.

\section{Acknowledgements}

I would like to thank Gregor Dorfleitner, Sebastian Utz, and an anonymous referee for valuable comments and suggestions. This work was supported by the German Research Foundation (DFG) within the funding program Open Access Publishing.

\section{References}

Bauer, R., Koedijk, K., \& Otten, R. (2005). International evidence on ethical mutual fund performance and investment style. Journal of Banking \& Finance, 29, 1751-1767. http://dx.doi.org/10.1016/j.jbankfin.2004.06.035

Barracchini, C., \& Adessi, M. E. (2012). Ethical portfolio theory: A new course. Journal of Management and Sustainability, 2(2), 35-42. http://dx.doi.org/10.5539/jms.v2n2p35

Brammer, S., Brooks, C., \& Pavelin, S. (2006). Corporate social performance and stock returns: UK evidence from disaggregate measures. Financial Management, 35, 97-116. http://dx.doi.org/10.1111/j.1755-053X.2006.tb00149.x

Bollen, N. P. B. (2005). Short-term persistence in mutual fund performance. Review of Financial Studies, 18, 569-597. http://dx.doi.org/10.1093/rfs/hhi007

Bollen, N. P. B. (2007). Mutual fund attributes and investor behavior. Journal of Financial and Quantitative Analysis, 42, 683-708. http://dx.doi.org/10.1017/S0022109000004142

Capelle-Blancard, G., \& Monjon, S. (2012). Trends in the literature on socially responsible investment: Looking for the keys under the lamppost. Business Ethics: A European Review, 21, 239-250. http://dx.doi.org/10.1111/j.1467-8608.2012.01658.x

Carhart, M. M. (1997). On persistence in mutual fund performance. Journal of Finance, 52, 57-82. http://dx.doi.org/10.1111/j.1540-6261.1997.tb03808.x

Derwall, J., Guenster, N., Bauer, R., \& Koedijk, K. (2005). The eco-efficiency premium puzzle. Financial Analysts Journal, 61(2), 51-63. http://dx.doi.org/10.2469/faj.v61.n2.2716

Dorfleitner, G., \& Utz, S. (2012). Safety first portfolio choice based on financial and sustainability returns. European Journal of Operational Research, 221, 155-164. http://dx.doi.org/10.1016/j.ejor.2012.02.034

Edmans, A. (2011). Does the stock market fully value intangibles? Employee satisfaction and equity prices. Journal of Financial Economics, 101, 621-640. http://dx.doi.org/10.1016/j.jfineco.2011.03.021 
Guerard, J. (1997). Is there a cost to being socially responsible in investing? Journal of Forecasting, 16, 475-490. http://dx.doi.org/10.1002/(SICI)1099-131X(199712)16:7<475::AID-FOR668>3.0.CO;2-X

Hamilton, S., Jo, H., \& Statman, M. (1993). Doing well while doing good: The investment performance of socially responsible mutual funds. Financial Analysts Journal, 49(6), 62-66. http://dx.doi.org/10.2469/faj.v49.n6.62

Hendricks, D., Patel, J., \& Zeckhauser, R. (1993). Hot hands in mutual funds: Short-run persistence of relative $\begin{array}{llll}\text { performance, 1974-1988. Journal of } & \text { Finance, }\end{array}$ http://dx.doi.org/10.1111/j.1540-6261.1993.tb04703.x

Hill, R. P., Ainscough, T., Shank, T., \& Manullang, D. (2007). Corporate social responsibility and socially responsible investing: A global perspective. Journal of Business Ethics, 70, 165-174. http://dx.doi.org/10.1007/s10551-006-9103-8

Hong, H., \& Kacperczyk, M. (2009). The price of sin: The effect of social norms on markets. Journal of Financial Economics, 93, 15-36. http://dx.doi.org/10.1016/j.jfineco.2008.09.001

Kempf, A., \& Osthoff, P. (2007). The effect of socially responsible investing on portfolio performance. European Financial Management, 13, 908-922. http://dx.doi.org/10.1111/j.1468-036X.2007.00402.x

Kurtz, L., \& DiBartolomeo, D. (1996). Socially screened portfolios: An attribution analysis of relative performance. Journal of Investing, 5(3), 35-41. http://dx.doi.org/10.3905/joi.1996.35

Luck, C., \& Pilotte, N. (1993). Domini social index performance. Journal of Investing, 2(3), 60-62. http://dx.doi.org/10.3905/joi.2.3.60

Mănescu, C. (2011). Stock returns in relation to environmental, social and governance performance: Mispricing or compensation for risk? Sustainable Development, 19, 95-118. http://dx.doi.org/10.1002/sd.510

Moskowitz, M. (1972). Choosing socially responsible stocks. Business and Society Review, 1, 71-75.

Renneboog, L., Ter Horst J., \& Zhang, C. (2008a). Socially responsible investments: Institutional aspects, performance, and investor behavior. Journal of Banking \& Finance, 32, 1723-1742. http://dx.doi.org/10.1016/j.jbankfin.2007.12.039

Renneboog, L., Ter Horst, J., \& Zhang, C. (2008b). The price of ethics and stakeholder governance: The performance of socially responsible mutual funds. Journal of Corporate Finance, 14, 302-322. http://dx.doi.org/10.1016/j.jcorpfin.2008.03.009

Schröder, M. (2007). Is there a difference? The performance characteristics of SRI equity indices. Journal of Business Finance and Accounting, 34, 331-348. http://dx.doi.org/10.1111/j.1468-5957.2006.00647.x

Statman, M., \& Glushkov, D. (2008). The wages of social responsibility. Financial Analysts Journal, 65(4), 33-46. http://dx.doi.org/10.2469/faj.v65.n4.5

US Social Investment Forum. (2010). Report on socially responsible investing trends in the United States [Executive Summary]. Retrieved from http://ussif.org/resources/pubs/trends/documents/2010TrendsES.pdf

\section{Notes}

Note 1. There are several rating agencies specialized in assessing these ESG-scores. In practice, these agencies evaluate data from various sources - for instance, company filings, media, governments, third-party data providers, and NGOs - on numerous sub-topics regarding corporate social responsibility. Thereby, numerous sub-scores are generated, which are eventually condensed into a single composite ESG-score for each company.

Note 2. The exact datatypes in Datastream are ENVSCORE, SOCSCORE, and CGVSCORE.

Note 3. I also tried different rank schemes-for instance, putting funds that are exactly on the threshold between two rank portfolios into the lower ranked portfolio. This did not materially affect any of the results. 